\title{
SUMBER DAYA IKAN PERAIRAN UMUM DARATAN DI INDONESIA-TERABAIKAN
}

\author{
Endi Setiadi Kartamihardja ${ }^{1)}$, Kunto Purnomo²), dan Chairulwan Umar1) \\ 1) Peneliti pada Pusat Riset Perikanan Tangkap, Ancol-Jakarta \\ 2) Peneliti pada Loka Riset Pemacuan Stok Ikan, Jatiluhur-Purwakarta \\ Teregistrasi I tanggal: 6 Pebruari 2007; Diterima setelah perbaikan tanggal: 26 Maret 2008; \\ Disetujui terbit tanggal: 25 April 2008
}

\begin{abstract}
ABSTRAK
Perairan umum daratan Indonesia mempunyai luas 13,85 juta ha yang terdiri atas 12,0 juta ha sungai dan paparan banjiran (flood plains), 1,8 juta ha danau alam (natural lakes) dan 0,05 juta ha danau buatan (man made lakes) atau waduk (reservoirs). Potensi perikanan tangkap di perairan umum daratan ditaksir mencapai 3.034.934 ton per tahun. Perairan umum daratan berperan penting sebagai sumber protein dan ketahanan pangan, sumber ekonomi masyarakat, sumber lapangan kerja, sumber plasma nutfah dan genetik, sumber devisa dan pendapatan asli daerah, serta obyek wisata alam (ecoturism). Perairan umum daratan yang terabaikan akan berdampak terhadap penurunan potensi luasnya, keanekaragaman jenis ikan, produksi ikan, kesempatan dan peluang kerja (peningkatan pengangguran), pendapatan asli daerah, dan fungsi estetika. Pengelolaan perairan umum dengan benar akan berpengaruh terhadap peningkatan produksi minimal $20 \%$ dan fungsi ekologis, sehingga perikanan perairan umum daratan dapat dijadikan tumpuan pembangunan perekonomian masyarakat, khususnya nelayan. Berbagai upaya yang dilakukan untuk membangun perikanan perairan umum daratan antara lain mempromosikan akan penting dan peranan sub sektor perikanan, memberikan perhatian terhadap riset di bidang sumber daya perikanan, melakukan valuasi sumber daya, melaksanakan monitoring dan evaluasi (termasuk perbaikan statistik perikanan), mengembangkan ko manajemen dan kapasitas sumber daya manusia.
\end{abstract}

KATAKUNCI: potensi produksi ikan, perikanan, pengelolaan bersama, perairan umum daratan, Indonesia

ABSTRACT: Inland fisheries resources of Indonesia-neglected. By: Endi Setiadi Kartamihardja, Kunto Purnomo, and Chairulwan Umar

Inland waters of Indonesia has a total area of 13.85 million ha composing of 12.0 million ha rivers and flood plains, 1.8 million ha natural lakes and 0.05 million ha man made lakes/ reservoirs. Total of fish potential yields of the inland waters was estimated to be 3,034,934 ton per yr. The inland waters plays an important role as source of protein and food security, source of economic and supporting livelihood of the peoples, source of employment, sources of genetics and germ plasm, contributing to foreign exchange and local government earning, and eco-tourism. The neglecting inland waters has affected on the decreasing potential area, fish potential yields, fish species diversity, employment opportunity, and local government earning and the ecological function. Management of the resources could impact on the increasing fish yields at least $20 \%$ and its ecological function, so that the inland waters fisheries can be used as a based of economic development of the peoples especially for the fishers. Some efforts which should be done in development of the inland waters fisheries are promotion of the role

Korespondensi Penulis:

JI. Pasir Putih I, Ancol Timur-Jakarta 14430, E-mail: endi_prpt@indo.net.id 
and importance of fisheries between other sectors, prioritizing research on fisheries resources, valuation of inland waters fisheries, monitoring and evaluation (including fisheries statistics), development of fisheries co-management and capacity building of the human resources.

\section{KEYWORDS: fish potential yield, fisheries, co-management, inland open waters, Indonesia}

\section{MENGAPA TERABAIKAN?}

Pada Forum Perairan Umum II yang diselenggarakan pada tanggal 22 Desember 2005 di Palembang disepakati bahwa istilah perairan umum yang pengertiannya sama dengan perairan darat ditetapkan sebagai perairan umum daratan, yaitu semua badan air yang terbentuk secara alami atau buatan dan terletak mulai garis pasang surut terendah ke arah daratan serta bukan milik perorangan. Dengan demikian, perairan umum daratan meliputi sungai dan paparan banjiran, danau, waduk, rawa, dan genangan air lainnya. Meskipun, dalam UndangUndang No.31 Tahun 2004 tentang Perikanan tidak tertulis istilah perairan umum daratan, namun pada Pasal 5 ayat (1) butir c mengatakan bahwa sungai, danau, waduk, rawa, dan genangan air lain sebagai wilayah pengelolaan perikanan Republik Indonesia.

Selain sektor perikanan, perairan umum daratan juga dimanfaatkan oleh berbagai sektor pemanfaat seperti pertanian, kehutanan, irigasi, pembangkit listrik tenaga air, pertambangan, sumber air untuk keperluan air baku industri dan rumah tangga, perhubungan (navigasi), dan pariwisata. Pemanfaatan perairan umum daratan yang multiguna tersebut berkompetisi dengan kegiatan perikanan dalam kaitan dengan modifikasi struktur lingkungan dan kualitas serta kuantitas air sehingga menjadikan perairan mendapat beban atau tekanan yang cukup bobot.

Berbagai hal kenapa perairan umum daratan terabaikan adalah sebagai berikut:
1 Perhatian pemerintah akan peranan penting perikanan perairan umum daratan masih kurang. Selama ini perhatian pemerintah hanya terfokus pada perikanan laut.

2 Sektor perikanan perairan umum daratan dalam konteks pemanfaatan multiguna ditempatkan pada prioritas terendah di antara sektor pemanfaat lain. Sebagai contoh proyek pembukaan lahan gambut 1 juta ha di Kalimantan Tengah telah mengabaikan perikanan beje sehingga sekitar 1.839 buah beje yang terdapat di Kabupaten Kapuas menjadi kering, tidak berfungsi dan tidak menghasilkan ikan lagi. Mega proyek tersebut berdampak negatif terhadap penurunan produksi dan keanekaragaman jenis ikan dengan total nilai kerugian dari produksi ikan ditaksir Rp.17 milyar (Kartamihardja, 2002).

3 Perairan umum daratan sering dianggap sebagai tempat buangan limbah sehingga merugikan perikanan. Sektor perikanan yang tidak mengkonsumsi air tetapi untuk kelangsungan hidup dan kehidupan ikan dan organisme akuatik lain membutuhkan kualitas dan kuantitas air yang memadai, akan terkena dampak pemanfaatan yang paling awal.

4 Data dan informasi tentang potensi sumber daya ikan yang sesungguhnya dan cukup besar belum banyak diketahui terutama oleh para pengambil kebijakan yang terkait dengan pemanfaatan perairan umum daratan.

Sehubungan dengan itu, pembangunan perikanan perairan umum daratan untuk perikanan yang sesungguhnya ditempatkan 
dalam konteks pembangunan sumber daya perairan secara terpadu dengan melibatkan seluruh sektor pemanfaat. Dalam hal ini, perikanan sebagai salah satu sektor pemanfaat perairan umum daratan ditempatkan sejajar dengan sektor pemanfaat lain.

\section{BERAPA BESAR POTENSI SUMBER DAYA IKAN PERAIRAN UMUM?}

\section{Potensi Lahan}

Perairan umum daratan Indonesia ditaksir seluas 13,85 juta ha yang terdiri atas 12,0 juta ha sungai dan paparan banjiran (flood plains), 1,8 juta ha danau alam (natural lakes), dan 0,05 juta ha danau buatan (man made lakes) atau waduk (reservoirs) (Sukadi \& Kartamihardja, 1995). Indonesia memiliki sekitar 5.590 sungai utama dengan panjang total mencapai $94.573 \mathrm{~km}$ dan sekitar 65.017 anak sungai (Depkimpraswil, 2003). Paparan banjir adalah lahan datar di sekitar sungai yang digenangi air saat banjir, yaitu saat daya tampung alur sungai terlampaui sehingga air meluap. Paparan banjir berupa danaudanau dangkal musiman, hutan rawa air tawar, atau rawa semak. Pada musim banjir, paparan banjir dapat berbentuk sistem danau yang besar atau berupa danau-danau kecil yang saling terhubungkan. Sebaliknya pada musim kemarau, aliran membalik dan paparan banjir berfungsi untuk mengisi badan air sungai. Indonesia juga memiliki sekitar 840 danau dan 735 situ (danau kecil) serta sekitar 162 waduk (Depkimpraswil, 2003).

Luas perairan umum daratan tersebut $65 \%$ dari luas total berada di Kalimantan, 23\% di Sumatera, 7,8\% di Papua, 3,5\% di Sulawesi, serta 0,7\% di Jawa, Bali, dan Nusa Tenggara (Sarnita, 1986). Luas lahan perairan umum daratan ini selalu berubahubah, selain karena fluktuasi air antara musim hujan dan kemarau, juga karena ada pembentukan waduk-waduk baru, reklamasi lahan rawa banjiran dan konversi lahan perairan umum daratan menjadi lahan daratan untuk kegunaan lain. Oleh karena itu, untuk keperluan pembangunan perikanan diperlukan penaksiran kembali luasan perairan tersebut.

\section{Potensi Sumber Daya Ikan}

Sebagai sumber plasma nutfah dan genetik, perairan umum daratan Indonesia memiliki keanekaragaman jenis ikan yang tinggi, sehingga tercatat sebagai salah satu perairan dengan mega biodiversity di dunia. Komisi Nasional Plasma Nutfah Indonesia mengatakan bahwa perairan umum daratan Indonesia mengandung kekayaan plasma nutfah ikan yang jenisnya sangat banyak, mencapai $25 \%$ dari jumlah jenis ikan yang ada di dunia. Perairan umum daratan Indonesia yang meliputi Sumatera, Jawa, Kalimantan, dan Sulawesi dihuni oleh lebih dari 1000 jenis ikan (Kottelat et al., 2005), bahkan menurut FAO, perairan umum daratan Indonesia dihuni oleh sekitar 2000 jenis ikan. Banyak di antara jenis ikan yang ada belum tercatat atau belum teridentifikasi sehingga jumah jenis dari tahun ke tahun selalu bertambah.

Dewasa ini, kemajuan ilmu pengetahuan dan teknologi untuk identifikasi ikan dengan menggunakan DNA telah menambah catatan kekayaan jenis ikan di Indonesia. Sebagai contoh, jenis ikan yang termasuk famili Pangasidae (jenis-jenis patin/catfish) yang semula hanya dikenal 6 jenis, kini dengan menggunakan identifikasi DNA ternyata jenis-jenis ikan patin tersebut diketahui menjadi 12 jenis (Balai Penelitian Perikanan Air Tawar, 2000), begitu pula dengan jenis-jenis ikan arwana (Scleropages spp.) yang semula hanya dikenal 2 jenis, yaitu $S$. formosus dan $S$. jardinii ternyata ada 5 jenis (Instalasi Riset 
Pemuliaan Ikan Air Tawar, 2005). Akhir-akhir ini juga diperkenalkan dengan penemuan jenis ikan terkecil di dunia dari famili Cyprinidae, yakni Paedocypris progenetica yang pada ukuran dewasa hanya mempunyai panjang total 7,9 $\mathrm{mm}$, hidup di perairan rawa masam berair hitam (black waters) di Sumatera dengan $\mathrm{pH}$ air 3 (Kottelat et al., 2005). Kekayaan keanekaragaman jenis ikan yang tinggi tersebut merupakan modal dasar penting dan tak ternilai bagi pembangunan perikanan perairan umum daratan masa depan.

\section{Potensi Produksi Ikan}

Berdasarkan pada hasil-hasil riset mengenai potensi produksi ikan di beberapa perairan danau dan waduk di Indonesia yang ditaksir menggunakan produktivitas primer dan indeks morfoedafik (Sarnita et al., 1997), maka pada tahun 2005, Kartamihardja (in press) melakukan pendugaan potensi produksi ikan untuk perairan umum daratan Indonesia dengan pendekatan empiris dari tipe kelompok badan air yaitu danau, waduk, sungai, dan paparan banjiran. Persamaan empiris untuk pendugaan potensi produksi ikan di perairan danau dan waduk, masing-masing sebagai berikut:

1. Perairan Danau: $P I_{D}=0,1317^{*} A^{0,972}$ $\left(N=26 ; R^{2}=0,610\right)$ .. (1

2. Perairan Waduk: $P I_{W}=4,0519 * A^{0,709}$ $\left(\mathrm{N}=12 ; \mathrm{R}^{2}=0,782\right)$

di mana:

$$
\begin{aligned}
\mathrm{PI}_{\mathrm{D}}= & \text { potensi produksi ikan perairan } \\
& \text { danau (ton per th) } \\
\mathrm{PI}_{\mathrm{W}}= & \text { potensi produksi ikan perairan } \\
& \text { waduk (ton per th) } \\
\mathrm{A}= & \text { luas lahan danau atau waduk } \\
& \text { (ha) } \\
\mathrm{N}= & \text { jumlah badan air yang diteliti }
\end{aligned}
$$

Untuk pendugaan potensi produksi ikan di perairan sungai dan paparan banjiran digunakan model sederhana sebagai berikut:

$$
P I_{S}=Y * A
$$

di mana:

$$
\begin{aligned}
\mathrm{PI}_{\mathrm{S}}= & \text { potensi produksi ikan di perairan } \\
& \text { sungai (ton per th) } \\
\mathrm{Y}= & \text { rata-rata produksi ikan (ton) } \\
\mathrm{A}= & \text { luas sungai dan paparan } \\
& \text { banjiran (ha) }
\end{aligned}
$$

Jika estimasi potensi produksi tersebut digunakan data yang tersedia untuk perairan sungai dan paparan banjiran di Kalimantan Barat, Jambi, dan Sumatera Selatan yang berkisar antara 38 sampai dengan 793 kg per ha dengan rata-rata $239 \mathrm{~kg}$ per ha (Aeron-Thomas et al., 2003) didapat nilai estimasi 2.868.000 ton per tahun sehingga total potensi produksi ikan di perairan umum daratan Indonesia menjadi 3.034.934 ton per tahun (Tabel 1). Dengan demikian, jika data potensi produksi ikan yang terakhir yang dipakai, maka meskipun luas perairan umum daratan Indonesia hanya 0,32\% dari luas perairan umum bahari, namum potensi produksi ikan sekitar 50\% dari potensi produksi lestari ikan laut yang mencapai 6,4 juta ton per tahun (Badan Riset Kelautan dan Perikanan-Departemen Kelautan dan Perikanan dan Pusat Penelitian Oseanografi-Lembaga Ilmu Pengetahuan Indonesia, 2001). Hal ini juga menandakan bahwa dengan pengelolaan yang rasional, perairan umum daratan Indonesia dapat dijadikan andalan sebagai tumpuan pembangunan masyarakat pedesaan bagi peningkatan kesejahteraan mereka. Berdasarkan pada data statistik perikanan diketahui bahwa rata-rata produksi ikan dari perikanan tangkap di perairan umum daratan Indonesia yang telah dicapai 325.000 ton per tahun dan apabila data ini dianggap di bawah estimasi sesungguhnya 
(under reported) yang dikalikan faktor 2,5 sampai dengan 3,6 (Coates, 2002) atau rata-rata 3 , maka tingkat pemanfaatan sumber daya ikan yang telah dicapai $3 \times 325.000$ ton $=975.000$ ton per tahun atau baru 32\% dari total potensi. Apabila produksi ikan lestari yang dialokasikan 60\% dari total potensi atau 1.820.960 ton per tahun, maka produksi perikanan tangkap di perairan umum daratan sesungguhnya dapat ditingkatkan 845.960 ton per tahun atau sekitar $87 \%$ dari produksi ikan yang telah dicapai saat ini.

Tabel 1. Estimasi potensi produksi ikan perairan umum daratan Indonesia

Table 1. Estimated potential production of fish in inland waters of Indonesia

\begin{tabular}{lccc}
\hline $\begin{array}{c}\text { Tipe ekosistem perairan/ } \\
\text { Type of waters ecosistem }\end{array}$ & $\begin{array}{c}\text { Luas/Width } \\
\text { (ha) }\end{array}$ & $\begin{array}{c}\text { Estimasi potensi produksi } \\
\text { ikan/Potential estimation of fish } \\
\text { production (ton/th) }\end{array}$ & $\begin{array}{c}\text { Rata-rata potensil } \\
\text { Average of potency } \\
\text { (kg/ha/th) }\end{array}$ \\
\hline Danau & 1.800 .000 & 158.162 & 88 \\
Waduk & 50.000 & 8.772 & 174 \\
Sungai dan paparan banjiran & 12.000 .000 & 2.868 .000 & $2391)$ \\
\hline Total & 13.850 .000 & $\mathbf{3 . 0 3 4 . 9 3 4}$ & \\
\hline
\end{tabular}

Keterangan/Remarks: ${ }^{1)}$ berdasarkan pada data Aeron-Thomas et al. (2003) untuk perairan sungai di Indonesia

\section{BERAPA BESAR KONTRIBUSI YANG SUDAH DICAPAI?}

Ditinjau dari sektor perikanan, perairan umum daratan sebagai salah satu wilayah pengelolaan perikanan Republik Indonesia berperanan penting dalam hal sebagai berikut: sumber protein dan ketahanan pangan, sumber ekonomi masyaraka, sumber lapangan kerja, sumber plasma nutfah dan genetik, sumber devisa dan pendapatan asli daerah, dan obyek wisata alam (ecoturism).

\section{Sumber Protein dan Ketahanan Pangan}

Sejak manusia menghuni bumi Indonesia, ikan sebagai produk perikanan perairan umum daratan yang dihasilkan melalui perburuan sudah merupakan salah satu sumber protein hewani bagi kehidupan. Sampai dengan saat ini, bagi masyarakat terutama yang tinggal jauh dari laut, ikan merupakan sumber protein utama dan ketahanan pangan yang harganya relatif terjangkau. FAO (2002) mengatakan bahwa di Dunia, sekitar $12 \%$ dari total produk perikanan tangkap (meskipun pada kenyataan mungkin lebih tinggi) perairan umum daratan dikonsumsi oleh masyarakat. Bagi masyarakat di Sumatera bagian selatan, Kalimantan, dan Sulawesi, konsumsi ikan air tawar cukup tinggi dan masyarakat lokal menjadikan sebagai sumber protein utama dan mikro nutrien.

Di antara negara produsen perikanan tangkap di perairan umum daratan di Dunia, Indonesia menempati posisi ke-5 setelah Uganda, dari 10 negara produser tertinggi, seperti tertera pada Gambar 1 (FAO, 2002).

Kontribusi produksi ikan dari perairan umum daratan ke-10 negara produser terbesar tersebut $64 \%$ dari total produksi ikan perairan umum daratan dunia (FAO, 1999b).

Produksi ikan perairan umum daratan Indonesia selama kurun waktu tahun 1960 sampai dengan 2006 berfluktuasi antara 228.571 sampai dengan 364.875 ton dengan rata-rata 290.260 ton per tahun dan sejak tahun 1995 mengalami stagnasi (Gambar 2). Selama kurun waktu tersebut juga terlihat bahwa persentase kontribusi 
produksi perikanan tangkap terhadap total produksi ikan (produksi perikanan tangkap diperlukan upaya pemulihan dan dan budi daya) terus menurun sehingga peningkatan produksi.

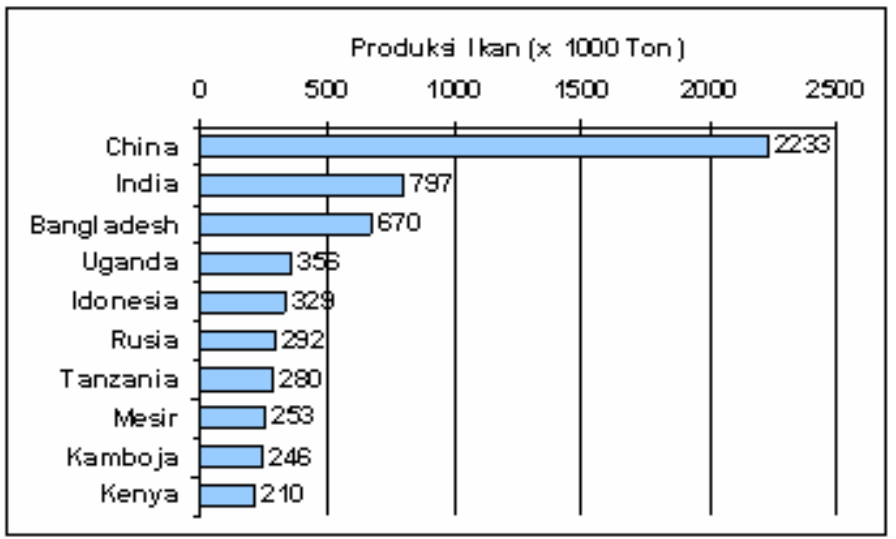

Gambar 1. 10 negara terbesar penghasil ikan perairan umum daratan di dunia. Sumber: FAO (2002)

Figure $1 . \quad$ The biggest 10 countries producing inland waters fishes in the world. Source: FAO (2002)

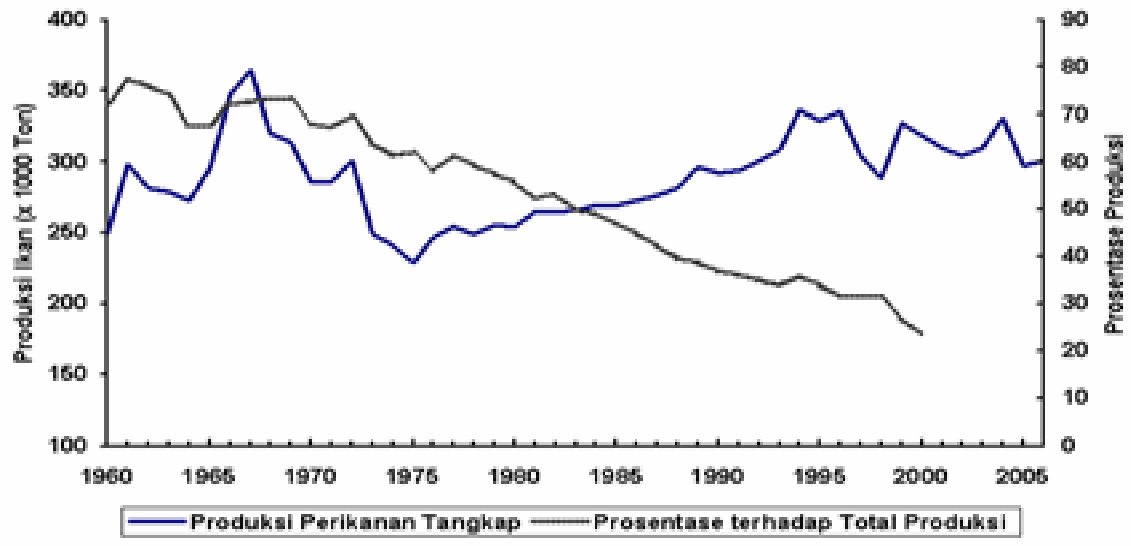

Gambar 2. Produksi perikanan tangkap dan persentasenya terhadap total produksi ikan perairan umum daratan, 1960 - 2006.

Figure 2. Production of capture fishery and its percentage of fish production total of inland waters, 1960 - 2006.

Produk ikan yang dihasilkan dari kegiatan perikanan tangkap sesungguhnya diperkirakan 2 sampai dengan 7 kali lebih tinggi dari produksi ikan yang tercatat secara resmi (FAO, 1999a) sehingga secara umum hasil tangkapan yang sesungguhnya di perairan umum daratan negara-negara
Asia Tenggara (Indonesia, Malaysia, Myanmar, Philippines, dan Thailand) dikalikan dengan faktor 2,5 sampai dengan 3,6 (Coates, 2002). Kesulitan pencatatan produksi ikan menjadi penyebab rendah pencatatan produksi ikan dari yang sesungguhnya. Hal ini, antara lain 
disebabkan oleh tersebarnya sentra-sentra produksi dalam jangkauan yang berjauhan, berskala relatif kecil serta produk yang dihasilkan banyak yang dikonsumsi sendiri. Sebagai contoh, produk ikan yang dihasilkan dari kegiatan perikanan tangkap di Waduk Djuanda, Jatiluhur yang dicatat oleh enumerator setiap hari di tempat pendaratan ikan pada tahun 2003 dan 2004 rata-rata $1.426,5$ ton atau 1,7 kali lipat (Kartamihardja \& Umar, 2005) dibandingkan dengan catatan resmi yang rata-rata hanya 855,6 ton (Dinas Peternakan dan Perikanan Kabupaten Purwakarta, 2004). Demikian pula, produksi perikanan tangkap di Waduk Riam Kanan, Kalimantan Selatan yang pada tahun 2003 hanya tercatat 431,5 ton (Dinas Perikanan dan Kelautan Propinsi Kalimantan Selatan, 2003) dibandingkan dengan hasil pencatatan oleh enumerator setiap hari di tempat pendaratan ikan yang mencapai 560 ton (Kartamihardja et al., 2004). Bahkan produksi ikan di Danau Sembuluh, Kalimantan Tengah tidak khusus tercatat secara resmi, padahal produksi ikan tangkapan mencapai 204 ton, begitu pula dengan produksi udang galah (Macrobrachium rosenbergii) di perairan yang sama yang mencapai 15,2 ton pada tahun 2004 (Kartamihardja et al., 2005).

\section{Sumber Ekonomi Masyarakat}

Meskipun hanya merupakan bagian kecil dari wilayah pengelolaan perikanan Indonesia (0,32\% luas laut Indonesia), sistem perikanan perairan umum daratan mempunyai arti dan berperan penting bagi masyarakat kecil, terutama masyarakat pedesaan. Pada umumnya perikanan perairan umum daratan bersifat skala kecil, di mana pendaratan ikan hasil tangkapan dilakukan dan terpencar di beberapa tempat sehingga sering tidak tercatat dan hasil tangkapannya dikonsumsi terutama untuk memenuhi keperluan lokal atau sendiri.
Pelaku kegiatan ekonomi di perikanan tangkap perairan umum daratan adalah keluarga nelayan dan hampir tidak ada sistem hubungan majikan-buruh nelayan, kecuali di Kabupaten Ogan Komering Ilir dan Musi Banyuasin, Sumatera Selatan yang perairan umum daratan dikuasai oleh perorangan melalui lelang. Di wilayah perairan umum daratan ini, nelayan menyewa kawasan tangkapan pada pemenang lelang yang disebut pengemin.

Pada umumnya, sistem sosial masyarakat nelayan di perairan umum daratan lebih egaliter. Pemasaran produk atau hasil tangkapan merupakan perwujudan nyata perekonomian yang berbasis kerakyatan. Hal ini berbeda dengan kegiatan budi daya perikanan di perairan umum daratan yang cenderung menampakkan ciri perekonomian yang kapitalistik atau padat modal.

Berbeda dengan nelayan di perairan laut, nelayan di perairan umum daratan memasarkan produk perikanan tangkap melalui transaksi ekonomi yang tidak melibatkan sistem ijon, tetapi lebih bersifat tunai. Nelayan atau keluarga memungkinkan untuk memasarkan produksi sendiri ke sentra-sentra konsumen. Kondisi demikian dengan produksi ikan yang tidak menentu dan bersifat subsisten, perikanan perairan umum daratan sering diabaikan dan dinilai rendah oleh pengambil kebijakan.

Selama ini, selain produk ikan konsumsi, produk ikan yang berupa ikan hias air tawar banyak yang belum digali dan dimanfaatkan secara optimum. Berbagai jenis produk seperti labi-labi, buaya, dan jenis reptilia lainnya merupakan produk yang belum dikelola secara rasional sebagai sumber perekonomian masyarakat, meski ada beberapa jenis hewan tersebut yang sudah dilindungi. 


\section{Sumber Lapangan Kerja}

Perikanan perairan umum daratan merupakan sumber mata pencaharian dan lapangan kerja bagi masyarakat miskin dan pekerja sambilan atau musiman. Pekerjaan mereka berhubungan dengan aktivitas lain seperti pertanian, peternakan, dan kehutanan. Pada tahun 2002, nelayan yang beroperasi di perairan umum daratan Indonesia tercatat sekitar 618.500 orang, terdiri atas 141.000 nelayan penuh (full time), 370.000 nelayan sambilan utama (major part time), dan 107.500 nelayan sambilan tambahan (minor part time) (Direktorat Jenderal Perikanan Tangkap, 2004). Jumlah nelayan tersebut dipastikan lebih besar karena banyak lapangan kerja lain selain nelayan yang terlibat dalam kegiatan perikanan, seperti pedagang ikan, pengolah ikan, pembuat perahu, dan alat perikanan. Selain itu, nelayan di perairan umum daratan tidak pernah memiliki identitas dan surat ijin penangkapan seperti pada kegiatan perikanan tangkap di laut sehingga jumlah secara akurat susah ditetapkan.

Oleh karena itu, kebanyakan badan air bersifat musiman, perpindahan pekerjaan dan daerah kerja menjadi terjadi di perikanan perairan umum daratan sehingga perairan umum daratan sering menyediakan lapangan kerja musiman untuk masyarakat dari sektor lain. Keanekaragaman jenis ikan dan keragaman ekosistem perairan umum daratan yang besar menciptakan suatu keragaman relung kehidupan di mana kelompok-kelompok yang berbeda dapat bekerja pada kegiatan perikanan tangkap.

\section{Sumber Plasma Nutfah dan Genetik}

Perairan umum daratan Indonesia memiliki kekayaan jenis ikan air tawar yang tinggi sebagai sumber plasma nutfah dan genetik seperti telah diuraikan pada sub bab potensi sumber daya ikan.

\section{Sumber Devisa dan Pendapatan Asli Daerah}

Perairan umum daratan sebagai sumber devisa dan pendapatan asli daerah dianggap rendah sehingga kontribusi terhadap keuangan negara dianggap terlalu kecil. Padahal, jika dinilai secara rinci dari produksi ikan konsumsi yang mencapai 325.000 ton per tahun dengan harga ratarata ikan Rp.8.000,- per kg, maka akan dihasilkan Rp.2,6 trilyun. Uang sebesar ini beredar dalam perekonomian masyarakat di daerah. Nilai ini akan lebih besar lagi jika dihitung nilai produksi ikan hias, misal arwana merah (super red arwana) yang harga pada ukuran panjang 8 sampai dengan $10 \mathrm{~cm}$ mencapai Rp.2,5 juta per ekor. Pada tahun 2005, nelayan di Kabupaten Merauke, Papua telah menghasilkan benih ikan arwana (Scleropages yardinii) 800.000 ekor dengan harga jual Rp.10.000,- per ekor sehingga dihasilkan nilai Rp.8 milyar (Dinas Perikanan dan Kelautan Kabupaten Merauke, pres com). Ikan hias lain adalah ikan botia (Botia macracantha) yang juga merupakan komoditi ekspor Indonesia. Selama tahun 1997 sampai dengan 1998 P.T. Wajok Inti Lestari (Pontianak, Kalimantan Barat) menampung ikan botia sejumlah 12 juta ekor dengan harga ikan botia dari nelayan di Kapuas Hulu (Kalimantan Barat) berkisar Rp.300 sampai dengan 500 per ekor (Henrie, 2004), sehingga dari Kalimantan Barat dapat dihasilkan senilai Rp.4,8 milyar. Jumlah tersebut belum termasuk ikan botia (Botia macracantha) yang ditangkap dari perairan umum daratan di Jambi dan Kalimantan Selatan, Tengah, dan Timur. Di perairan Sulawesi dan Papua juga banyak jenis-jenis ikan hias air tawar, seperti rainbow 
(Iriatherina werneri, Melanotaenia spp.) yang selama ini belum dimanfaatkan dan dikelola secara optimum.

Di Sumatera Selatan, khususnya di Kabupaten Ogan Komering llir dan Musi Banyuasin, kegiatan perikanan tangkap di perairan umum daratan yang dilakukan melalui lelang lebak lebung menjadi andalan sumber pendapatan asli daerah. Dalam tahun 1987 sampai dengan 1990, nilai hasil lelang perairan sungai dan rawa banjiran di Kabupaten Ogan Komering Ilir berkisar 290,8 sampai dengan Rp.316,5 juta di mana nilai ini terus meningkat dari tahun ke tahun (Nasution et al., 1993) dan pada periode tahun 2000 sampai dengan 2004, nilai lelang lebak lebung telah mencapai kisaran Rp.2,5 sampai dengan 4,4 milyar (Buku Perhitungan Anggaran Pendapatan Belanja Daerah Ogan Komering Ilir, Dinas Pendapatan Daerah Ogan Komering llir, 2000-2004). Landasan hukum dalam lelang lebak lebung ini dituangkan dalam Peraturan Daerah Kabupaten atau Kota Ogan Komering llir No.30 tahun 2002.

\section{Obyek Wisata Alam}

Perairan umum daratan Indonesia, selain mempunyai fungsi ekonomi dan keamanan pangan juga berfungsi menyediakan peluang untuk kegiatan yang bersifat aestetik, kultural, rekreasional, dan pendidikan, serta menyediakan rasa aman secara emosional, individual, kelompok masyarakat, dan lingkungan. Oleh karena itu, banyak perairan umum daratan yang dapat dijadikan sebagai obyek wisata alam karena badan-badan air tersebut mempunyai pemandangan alam dan fauna ikan yang indah dan menarik. Dalam hal ini, kerja sama antara sektor perikanan dengan sektor pariwisata akan memberikan andil yang besar bagi perekonomian bangsa.
Dari uraian tersebut di atas terlihat dengan jelas bahwa perikanan perairan umum daratan Indonesia mempunyai kontribusi yang sangat besar bagi kesejahteraan masyarakat. Oleh karena itu, upaya valuasi sumber daya perikanan perairan umum Indonesia yang selama ini belum pernah dilakukan akan memperlihatkan lebih nyata lagi bahwa perikanan perairan umum daratan Indonesia mempunyai nilai kontribusi yang nyata terhadap kesejahteraan masyarakat.

\section{APA TANTANGAN YANG DIHADAPI?}

\section{Degradasi Lingkungan}

Masalah atau isu kondisi lingkungan perairan akan semakin menonjol mana kala suatu badan air hendak dikembangkan untuk kegiatan perikanan, baik untuk budi daya maupun untuk perikanan tangkap. Ancaman terhadap kondisi suatu lingkungan perairan baik yang berupa penurunan kualitas air maupun pendangkalan di banyak badan air selalu terkait dengan aktivitas manusia di lahan atas sekitarnya (anthropogenic factor). Contoh jelas dapat dilihat di Waduk Saguling yang airnya berwarna hitam pekat akibat menerima limbah domestik atau perkotaan dari kota Bandung sehingga ikan tidak dapat hidup. Akibatnya tidak ada 1 nelayan pun di waduk tersebut. Contoh lain adalah perairan Danau Tempe di Sulawesi Selatan, Danau Semayang di Kalimantan Timur, dan Danau Limboto di Gorontalo yang semakin dangkal dan keruh air akibat penggundulan hutan di lahan atasnya yang berjalan secara intensif. Kondisi ini, apabila dibiarkan terus berlangsung, maka tidak mustahil dalam waktu yang tidak lama lagi akan kehilangan sumber daya ikan yang sangat potensial tersebut. Apabila dipetakan, maka secara keseluruhan akan terlihat bahwa perairan umum daratan Indonesia lama kelamaan akan semakin mengecil. 
Permasalahan tersebut di atas terutama disebabkan oleh kurang kepedulian pemerintah, baik pusat maupun daerah dan masyarakat itu sendiri dalam upaya melestariakan sumber daya perairan di sekitarnya. Dari sisi pemerintah, berdasarkan pada pengamatan di lapangan, hampir tidak pernah terlihat upaya pemerintah dalam menyelamatkan badanbadan air dalam wilayah perairan umum daratan. Kebanyakan pemerintah baru bertindak setelah badan air tersebut sudah rusak parah, atau mungkin memang sengaja dibiarkan hilang sehingga menjadi daratan. Khusus di sektor perikanan juga sangat terlihat bahwa pemerintah lebih disibukkan oleh urusan-urusan di perikanan laut yang sebenarnya sudah banyak disebutkan telah mengalami over fishing. Baru belakangan ini pemerintah mulai berkiprah di perairan umum daratan setelah dikejar sasaran pemenuhan produksi perikanan tangkap pada akhir tahun 2010.

\section{Peraturan dan Penegakan Hukum}

Seperti diketahui bahwa perairan umum daratan tidak hanya dimanfaatkan oleh sektor perikanan melainkan juga oleh sektor-sektor yang lain seperti transportasi atau perhubungan, pariwisata, pertanian, kelistrikan, dan lain-lain. Masing-masing sektor tersebut tentu menjalankan aktivitas sesuai dengan tujuan dan peraturan yang melandasinya. Akibatnya mungkin terjadi di suatu badan air akan terdapat berbagai peraturan yang mungkin satu sama lain akan saling tumpang-tindih atau bahkan bertentangan. Selain menonjol ego sektoral tadi, maka di era Otonomi Daerah seperti sekarang ini, ego kedaerahan atau kewenangan daerah terasa sangat menonjol. Hal ini dapat memicu terjadi konflik antar nelayan maupun dengan petugas di lapangan. Misalnya di Danau Tempe yang dikelola oleh beberapa kabupaten. Suatu kabupaten mungkin sedang menjalankan program pelestaian sumber daya ikan dengan cara melakukan penebaran ikan, tetapi kabupaten lain kurang peduli dengan hal itu, bahkan harga jual ikan di kabupaten ini relatif lebih baik sehingga nelayan di danau tersebut lebih memilih menjual ikan di kabupaten ke-2. Hal ini akan mudah menimbulkan konflik karena ada kepentingan dalam perolehan pendapatan asli daerah. Hal-hal semacam ini banyak terjadi di perairan umum daratan lain sehingga perlu segera diatasi misalnya dengan membentuk semacam Badan Otoritas yang diberi kewenangan untuk mengelola suatu badan air. Jadi badan ini nantinya yang akan menjalankan aspirasi tiap daerah yang berkepentingan dengan badan air tersebut.

\section{APA YANG AKAN TERJADI JIKA PERAIRAN UMUM DARATAN TERUS TERABAIKAN ATAU SEBALIKNYA JIKA DIKELOLA DENGAN BENAR?}

Berdasarkan pada data dan informasi tentang potensi sumber daya ikan dan peranan perikanan perairan umum daratan serta tantangan yang dihadapi seperti telah diuraikan pada bab sebelumnya, maka jika perikanan perairan umum daratan terus terabaikan akan terjadi hal-hal sebagai berikut:

1. Potensi lahan perairan umum daratan akan berkurang atau hilang. Sebagai contoh situ-situ di sekitar Bogor dan Jakarta yang pada tahun 1970 berjumlah 325 buah dan pada tahun 2000-an hanya tinggal kurang dari 50 buah (Sarnita, 2001). Dalam Seminar Pengelolaan Waduk dan Danau di Pusat Penelitian dan Pengembangan Sumber Daya Air, Bandung terungkap bahwa sekitar 500 danau dan waduk di Indonesia mulai terancam punah akibat pengelolaan dan pemanfaatan tidak optimal, mulai dari hulu sampai dengan hilir. Beberapa waduk dan danau 
mengalami pendangkalan akibat tingginya sedimentasi, misalnya Waduk Saguling, Cirata, dan Jatiluhur (Jawa Barat), Danau Tempe (Sulawesi Selatan), dan Waduk Wonogiri (Jawa Tengah). Sedangkan danau yang mengalami kerusakkan ekosistem antara lain Danau Limboto di Gorontalo, Danau Tondano (Sulawesi Utara), serta Danau Maninjau dan Danau Singkarak (Sumbar). Danau Limboto di Gorontalo yang pada tahun 1932 luasnya mencapai 7.000 ha telah menyusut menjadi 2.700 ha pada tahun 2005 dan pada tahun 2025 akan menjadi daratan. Pembuatan saluran irigasi dengan cara penyodetan sungai di Proyek Lahan Gambut Sejuta Hektar di Kalimantan Tengah mengakibatkan kering dan hilangnya lahan perikanan beje.

2. Potensi sumber daya ikan menurun. Keanekaragaman jenis ikan air tawar yang cukup tinggi akan menurun dan bahkan terancam punah. Pembangunan bendungan (waduk) yang tidak mempertimbangkan pentingnya jalur ruaya ikan dan perubahan serta hilangnya habitat telah berdampak terhadap penurunan dan hilangnya jenis ikan asli dari sungai yang dibendung. Sebagai contoh Pembangunan Waduk Djuanda di Sungai Citarum, Jawa Barat telah mengakibatkan hilangnya 19 jenis ikan asli, termasuk ikan ekonomis penting seperti ikan patin (Pangasius djambal), belida (Notopterus chitala), dan lika (Wallago spp). Potensi ikan hias yang antara lain terdapat beberapa jenis ikan belum dimanfaatkan secara optimal jika terus terabaikan, maka nilai ekspor atau devisa dari ikan hias tidak termanfaatkan.

3. Potensi produksi Ikan yang tinggi mencapai 3,05 juta ton tidak optimal dimanfaatkan sehingga produksi ikan akan tetap stagnan atau bahkan terus menurun.
4. Akibat lain adalah kesempatan kerja akan hilang dan sebaliknya pengangguran akan meningkat.

5. Pendapatan nelayan juga akan menurun karena hasil tangkapan juga menurun.

6. Pendapatan asli daerah seperti yang terjadi dari hasil lelang lebak lebung di Sumatera Selatan akan menurun karena sumber daya ikan yang tersedia jika tidak dikelola dengan baik atau terabaikan juga akan menurun.

Sebaliknya jika perairan umum daratan diperhatikan dan dikelola dengan benar, maka akan terjadi hal-hal sebagai berikut:

1. Potensi sumber daya ikan dengan keanekaragaman jenis yang tinggi akan terjaga dan lestari.

2. Oleh karena itu, jika potensi produksi ikan tinggi, maka produksi ikan yang sesungguhnya dapat ditingkatkan. Produksi perikanan tangkap dapat ditingkatkan minimal 20\% melalui kegiatan pemacuan stok ikan di perairan danau dan waduk. Sebagai contoh introduksi ikan bilih di Danau Toba dapat meningkatkan hasil tangkapan ikan bilih 653 ton senilai Rp.3,9 milyar (Kartamihardja \& Purnomo, 2006).

3. Kesempatan kerja meningkat karena peluang memproduksi ikan juga meningkat.

4. Pendapatan nelayan meningkat. Sebagai contoh, penebaran ikan patin siam (Pangasius spp.) di Waduk Wonogiri telah meningkatkan pendapatan nelayan antara Rp.860.000 sampai 1.350 .000 per bulan. Penebaran udang galah (Macrobrachium rosenbergii) di Waduk Darma, Jawa Barat meningkatkan tambahan pendapatan nelayan antara Rp.3,2 sampai 6,5 juta per tahun.

5. Jika sumber daya ikan dikelola dengan baik, maka sumber daya ikan akan lestari dan hasil tangkapan serta pendapatan asli daerah akan meningkat. 
6. Apabila masalah pencemaran dapat dikendalikan, maka nilai estetika perairan umum daratan untuk wisata juga akan terjamin.

\section{BAGAIMANA DAN APA YANG DILAKUKAN UNTUK OPTIMASI PEMANFAATANNYA?}

Dewasa ini, paradigma pembangunan di Indonesia telah mengalami pergeseran yang disebabkan oleh faktor ekternal (era globalisasi) ataupun faktor internal, terutama krisis moneter dan ekonomi yang berlanjut, demokratisasi, dan otonomi daerah. Beberapa bentuk pergeseran paradigma yang mendasar adalah sentraslisasi versus desentralisasi, pertumbuhan ekonomi versus pemerataan pendapatan, serta pembangunan konvensional yang bersifat ekstraktif versus pembangunan yang berkelanjutan. Dalam kaitannya dengan pembangunan perikanan perairan umum daratan dan berdasarkan pada status terkini mengenai potensi, tingkat pemanfaatan, dan status pengelolaan sumber daya perikanan perairan umum daratan serta isu dan permasalahan, maka strategi kunci pembangunan perikanan perairan umum daratan yang terutama diemban oleh pemerintah meliputi hal-hal sebagai berikut:

1. Merubah paradigma dari fokus produksi ikan menjadi fokus masyarakat di mana kebutuhan dan aspirasi masyarakat nelayan didengar dan dinilai, serta opini dan pendapat diperhatikan sehingga berfokus pada nilai produksi sebagai tolok ukur pendapatan. Pemacuan sumber daya ikan dilakukan dengan protokol yang jelas dan fokus pada peningkatan kualitas produksi.

2. Memberikan pengakuan dalam konteks pemanfaatan sumber daya perairan umum daratan yang multiguna. Pemerintah memberikan kemudahan dan kepastian dalam menentukan penguasaan akses, dan memayungi kompleksitas tersebut dengan pengembangan dan pembangunan secara lokal, pengelolaan secara adaptif dalam suatu konteks kehidupan yang melibatkan seluruh pengguna sumber daya perairan.

3. Membantu memecahkan potensi kemandegan antara penguasaan akses dan kepemilikan dan pengelolaan sumber daya perairan umum daratan secara berkelanjutan.

4. Reorientasi penelitian menjadi multidisiplin dan berorientasi kebutuhan masyarakat untuk menjembatani antara masyarakat dan pengambil kebijakan dengan melibatkan masyarakat nelayan dan menggali kearifan lokal. Di samping itu, valuasi sumber daya perikanan di perairan umum daratan dilakukan sehingga nilai kontribusi perikanan perairan umum daratan bagi kesejahteraan masyarakat akan terlihat nyata.

5. Menerapkan prinsip-prinsip pengelolaan perikanan yang bertanggungjawab sebagaimana tertuang dalam tata laksana perikanan yang bertanggungjawab (code of conduct for responsible fisheries) yang dikeluarkan oleh FAO (1997).

6. Meningkatkan dukungan perbaikan pengelolaan sumber daya perairan secara aktif, lebih transparan dan akuntabilitas melalui suatu kemitraan antara pemerintah dan pemanfaat sumber daya. Memberikan pengakuan bahwa tidak ada pengetahuan yang sederhana untuk memecahkan permasalahan pengelolaan di suatu daerah aliran sungai yang besar yang melewati batas propinsi. Dalam hal ini, kebijakan pembangunan perikanan perairan umum daratan diambil oleh Pemerintah Pusat.

7. Mempertahankan dan memelihara daya dukung lingkungan dengan mengurangi 
pengaruh yang merugikan dari kegiatan di dalam sektor maupun antar sektor pemanfaat.

8. Memberikan pengakuan bahwa sumber daya perairan umum daratan mempunyai kerentanan jenis dan keanekaragaman ekosistem. Melakukan pendekatan kehati-hatian dengan adanya pembangunan yang melakukan perubahan habitat atau fisik perairan, pola eksploitasi sumber daya, introduksi spesies dan pemacuan sumber daya ikan.

9. Mendukung identifikasi dan pengembangan yang dapat diterima dalam diversifikasi peluang kehidupan untuk masyarakat yang akan beralih pekerjaan dari sektor pemanfaat. Oleh karena itu, kegiatan perikanan di perairan umum daratan dipandang lebih luas, holistik dalam konteks pembangunan masyarakat pedesaan.

Penerapan ke-9 strategi kunci dalam pembangunan perikanan perairan umum daratan Indonesia perlu disesuaikan dengan karakteristik ekosistem, dan sosio ekonomi dan budaya masyarakat setempat sehingga akan memberikan distribusi keuntungan yang adil bagi kesejahteraan masyarakat.

\section{KESIMPULAN}

1. Perikanan perairan umum daratan Indonesia terabaikan, baik tentang peranan kepentingan, penempatan prioritas dalam pembangunan, anggapan sebagai tempat pembuangan limbah maupun informasi tentang potensi.

2. Perikanan perairan umum daratan Indonesia mempunyai potensi sumber daya ikan yang besar, baik potensi lahan $(13,85$ juta ha), keanekaragaman jenis ikan (sekitar 2000 jenis) dan potensi produksi ikan (3,05 juta ton per tahun).
3. Jika perairan umum terus terabaikan, maka akan terjadi penurunan potensi luas, keanekaragaman jenis ikan, produksi ikan, kesempatan dan peluang kerja (peningkatan pengangguran), pendapatan asli daerah dan fungsi estetika. Sebaliknya jika perikanan perairan umum diperhatikan dan dikelola dengan benar akan terjadi peningkatan produksi minimal $20 \%$ dan fungsi ekologis, sehingga perikanan perairan umum daratan dapat dijadikan tumpuan pembangunan perekonomian masyarakat, khusunya nelayan.

4. Berbagai upaya yang dilakukan untuk membangun perikanan perairan umum daratan antara lain mempromosikan akan penting dan peranan sub sektor perikanan, memberikan perhatian terhadap riset di bidang sumber daya perikanan, melakukan valuasi sumber daya, melaksanakan monitoring dan evaluasi (termasuk perbaikan statistik perikanan), dengan mengembangkan ko manajemen dan kapasitas sumber daya manusia.

\section{DAFTAR PUSTAKA}

Aeron-Thomas, M., S. Koeshendrajana, D. D. Hogarth, Z. Nasution, \& Samuel. 2003. An integrated assessment of Indonesian river fishery reserve. Part 4. Socio economics studies and distribution of fisheries costs and benefits. Indonesian Fisheries Research Journal. Vol.9. No.1.p. 20-26.

Balai Penelitian Perikanan Air Tawar. 2000. Poster jenis-jenis ikan patin di Indonesia. Pusat Penelitian dan Pengembangan Perikanan-ORSTOM. Perancis. Badan Penelitian dan Pengembangan Pertanian. Jakarta. 
Badan Riset Kelautan dan PerikananDepartemen Kelautan dan Perikanan dan Pusat Penelitian Oseanografi-Lembaga IImu Pengetahuan Indonesia. 2001. Laporan Akhir Pengkajian Stok Ikan di Perairan Indonesia. Pusat Penelitian dan Pengembangan Oseanologi-Lembaga Ilmu Pengetahuan Indonesia. Jakarta.

Coates, D. 2002. Inland Capture Fishery Statistics of Southeast Asia: Current Status and Information Needs. AsiaPacific Fishery Commission. Bangkok. Thailand. RAP Publication No.2002/11, 114 pp.

Dinas Pendapatan Daerah Ogan Komering Ilir. 2000-2004. Penghitungan Anggaran Pendapatan Belanja Daerah Ogan Komering Ilir.

Dinas Perikanan dan Kelautan Propinsi Kalimantan Selatan. 2003. Laporan Tahunan Statistik Perikanan dan Kelautan Kalimantan Selatan Tahun 2003. Pemerintah Propinsi Kalimantan Selatan. Dinas Perikanan dan Kelautan. Banjarbaru. 2004.

Dinas Peternakan dan Perikanan Kabupaten Purwakarta. 2004. Laporan tahunan statistik peternakan dan perikanan Kabupaten Purwakarta Tahun 2004.

Departemen Pemukiman dan Prasarana Wilayah. 2003. Data sumber daya air Indonesia. hppt://sda. kimpraswil.go.id.

Direktorat Jenderal Perikanan Tangkap. 2004. Statistik perikanan tangkap Indonesia tahun 2002. Departemen Kelautan dan Perikanan. 94 hal.

FAO. 2002. The State of World Fisheries and Aquaculture 2002. FAO. UN. Rome.
FAO. 1999a. Integrated Resource Management for Sustainable Inland Fish Production. Committee on Fisheries. Rome. Italy.

FAO. 1999b. Review of the states of world fisheries resources: Inland Fisheries. FAO Fisheries Circular No.942. FAO. UN. Rome.

FAO. 1997. A Technical Guidelines for Responsible Fisheries. No.6. Inland Fisheries. Rome.

Henrie, T. 2004. Profil perusahaan P.T. Wajok Inti Lestari. P.T. Wajok Inti Lestari. Pontianak. Kalimantan Barat. 15 hal.

Instalasi Riset Pemuliaan Ikan Air Tawar. 2005. Poster koleksi beberapa jenis ikan arwana. BRBAT. Pusat Riset Perikanan Budi Daya. Badan Riset Kelautan dan Perikanan. Departemen Kelautan dan Perikanan.

Kartamihardja, E. S. \& K. Purnomo. 2006. Penyelamatan populasi ikan bilih ke habitatnya yang baru di Danau Toba. Demersal. Dari Laut untuk Pembangunan. Edisi Maret 2006. Pusat Data dan Informasi. Departemen Kelautan dan Perikanan.

Kartamihardja, E. S .\& C. Umar. 2005. Technical report of capture fisheries component. Culture, Capture Conflicts: Sustaining Fish Production and Livelihoods in Indonesian Reservoir (Project No.FIS/2002/111). ACIAR and DGA. RI.

Kartamihardja, E. S., Wijopriono, K. Purnomo, \& Z. Fahmi. 2005. Kajian habitat dan stok ikan di daerah aliran Sungai Seruyan, Kalimantan Tengah dan 
daerah aliran Sungai Barito, Kalimantan Selatan. Laporan Teknis Hasil Riset. Pusat Riset Perikanan Tangkap. Badan Riset Kelautan dan Perikanan. Jakarta.

Kartamihardja, E. S., K. Purnomo, \& C. Umar. 2004. Trofodinamik dan struktur komunitas ikan di perairan danau dan waduk di Kalimantan Tengah dan Selatan. Laporan Teknis Hasil Penelitian Tahun 2004. Pusat Riset Perikanan Tangkap. Badan Riset Kelautan dan Perikanan. Departemen Kelautan dan Perikanan. (unpublish).

Kartamihardja, E.S. 2002. Pengaruh reklamasi Iahan rawa terhadap penurunan produksi dan perubahan komposisi jenis ikan pada usaha perikanan beje di Kabupaten Kapuas, Kalimantan Tengah. Jurnal Penelitian Perikanan Indonesia. Vol.8 No.4.

Kartamihardja, E. S. 2000. Strategi peningkatan stok ikan di perairan danau dan waduk Indonesia. Prosiding Semiloka Nasional Pengelolaan dan Pemanfaatan Danau dan Waduk. Jurusan Perikanan Fakultas Pertanian. Universitas Padjajaran. Bandung 7 Nopember 2000. 15 hal.

Kottelat, M., R. Britz, T. H. Hui, \& Kai-erik Witte. 2005. Paedocypris, a new genus of Southeast Asian cyprinid fish with a remarkable sexual dimorphism, comprises the world's smallest vertebrate. Procidding Royal Society. B. 5.

Nasution, Z., A. D. Utomo, \& D. Prasetyo. 1993. Lelang lebak lebung di Sumatera Selatan sebagai salah satu cara pengelolaan sumber daya perikanan perairan umum. Prosiding Temu Karya IImiah Perikanan Perairan Umum. Pengkajian Potensi dan Prospek Pengembangan Perairan Umum Sumatera Bagian Selatan. Palembang 12-13 Pebruari 1992. Prosiding. Puslitbangkan/No.26/1992. Badan Penelitian dan Pengembangan Pertanian. Departemen Pertanian. Hal. 122-134.

Sarnita, A. S. 1986. Inland Fisheries in Indonesia. Reports and papers presented at the Indo-Pacific Fishery Commission Expert Consultation on Inland Fisheries of the Larger IndoPacific Islands. Bangkok 4-9 August 1986. F.A.O. Rome. Italy. p. 60-71.

Sarnita, A. S., Kartamihardja, E.S., \& K. Purnomo. 1997. Ulasan tentang hasil penelitian perikanan perairan umum di Indonesia selama 1990-1996. Prosiding Simposium Perikanan Indonesia II. Ujung Pandang, 2-3 Desember 1997. Hal 81-92.

Sarnita, A.S. 2001. Penelitian limnologi situsitu di sekitar Jakarta-Bogor dan Bekasi. Laporan Hasil Penelitian Balai Penelitian Perikanan Air Tawar, Sukamandi. 28 hal.

Sukadi, M. F. \& E. S. Kartamihardja. 1995. Inland fisheries management of lakes and reservoirs with multiple uses in Indonesia. Regional Symposium on sustainable development of inland fisheries under environmental constrains. Bangkok. Thailand. 19-21 October 1994. FAO. UN.

Welcomme, R. L. 2001. Inland fisheries: Ecology and management. FAO. Blackwell Sci. Fishing News Books. 358 pp. 